\title{
ASSESSMENT OF CORNEAL ENDOTHELIAL CELL DENSITY AND MORPHOLOGY IN MYOPIC EYES BY SPECULAR MICROSCOPE
}

\author{
By \\ Mahmoud A. Al-sayyad, Magdy E. Khallaf and Hassan M. Bayoumi \\ Ophthalmology Department, Faculty of Medicine, Al-Azhar University, Egypt \\ Corresponding author: Mahmoud Ahmed Abdallah Al-sayyad, \\ E-mail: mahmoudelsayyad66@gmail.com
}

\begin{abstract}
Background: Corneal endothelium is responsible for maintaining corneal transparency throughout life by pumping excess fluid out of the stroma, and keeping stroma in its usual dehydrated state. It makes the measurement of central corneal thickness (MCD), cell size (CV) in the cell size, hexagonal appearance of the central corneal thickness $(\mathrm{CCT})$. These parameters provide an index of the functional status of corneal endothelial layer. Myopia is a common pathologic change of the eye.
\end{abstract}

Objective: To evaluate the corneal endothelial cell changes in myopic patients by indirect specular microscope.

Patients and methods: A prospective controlled study was carried out from June 2020 to February 2021 at Al-Hussein University Hospital, and a total of 120 eyes of myopic subjects aged 20-40 years old, 40 eyes were low myopia < -3.00 diobter, 40 eyes were moderate myopia from $(-3.00)$ to $(-6.00)$, and 40 eyes of high myopic subjects > -6.00 diopters sphere were recruited.

Results: Our results showed that corneal endothelial cell layer in high myopic eyes tended to have less endothelial cell density and cell hexagonality compared to moderate and low myopic eyes. Significance difference. Nevertheless, there was no significant difference in CCT between low and moderate myopic eyes. Also no significance difference in hexagonal cell percentage between high and moderate myopic eyes.

Conclusion: Myopia is a factor that affect the corneal endothelial cell density and morphology.

Keywords: Endothelial cell density (ECD), coefficient variation in the cell size (CV), hexagonal cells (HEX) central corneal thickness (CCT), myopia, Specular Microscopy.

\section{INTRODUCTION}

Corneal endothelium is the innermost layer of hexagonal non-replicating neural crest-derived tissue that is play an implitive role for maintaining corneal transparency throughout life by pumping excess fluid out of the stroma and keeping stroma in its usual dehydrated state (Sudhir et al., 2012). There is limited ability of mitosis in corneal endothelium and once damaged, remaining cells enlarge to cover up the lost area eye (Wong et al., 2014).

Myopia is a common pathologic change of the eye. High degrees of myopia are associated with increased risk of cataract, posterior vitreous detachment, retinal tears and retinal detachment, increased risk of choroidal neovascularization, and myopic macular degeneration (Younan et al., 2010). 
Non-contact specular microscope provides a non-invasive method of morphological analysis of the corneal endothelial cell layer. It makes the measurement of mean cell density (MCD), measurement of coefficient of variation (CV) in the cell size, central corneal thickness, as well as hexagonalv this parameters provide an index of functional status of endothelial layers (McCarey et al., 2011).

The present study aimed to evaluate the corneal endothelial cell changes in myopic eyes low, moderate and high myopic eyes by indirect specular microscope device.

\section{PATIENTS AND METHODS}

A prospective controlled study was carried out from July 2020 to Feb 2021 at Al-Hussein University Hospital, and a total of 120 eye from 60 subjects aged 2040 years old, 40 of eyes were low myopic (<-3.00D), 40 were moderate myopic up to $-6.00 \mathrm{D}$, and the others were high myopic (above -6.00 diopters sphere (and below 1.50 diopters cylinder), were recruited.

We excluded any subject with any type of corneal dystrophy, glaucoma, medical disease that could affect the eye, ocular pathology (except myopia and myopia associated chorioretinal changes), and history of previous contact lens wear, ocular trauma, LASIK, ocular, systemic disease or/and surgery.

A complete ophthalmic history was taken. Non-cycloplegic refraction was measured with an auto refractometer (Nidek AR-600). Uncorrected visual acuity (UCVA) and best corrected visual acuity (BCVA) measured using log MAR chart.

Complete ophthalmic examination included slit lamp biomicroscopy of the anterior segment (keeler 25z), applanation tonometry (keeler D-KAT), indirect ophthalmoscopy and slit lamp bio microscopy using Volk $+90 \mathrm{D}$ for fundus examination.

A complete ophthalmic history and ophthalmological examination were done for each subject which comprised of:

- Uncorrected visual acuity (UCVA) using Snellen's chart.

- Best corrected visual acuity (BCVA).

- Anterior segment detailed slit lamp examination (Keeler 25z).

- Intraocular pressure measurement by applanation tonometer (Keeler).

- Posterior segment examination using indirect ophthalmoscopy (Keeler).

\section{Methods:}

A non-contact specular microscope (Topcon SP2000P, Tokyo, Japan) was used to assess the central corneal endothelium, and each measurement was taken between 10:00 and11:00 a.m. by a single examiner. The procedure for specular microscopy was: three images from the central cornea and captured of at least 80 contiguous cells, and manually marked with a mouse by the examiner for analysis by a built-in software program. 
The computer automatically evaluated, calculated and displayed the mean cell density, CV, and percentage of hexagonal cells. The mean of each variable from the three best images of central cornea was used for MCD, CV, CCT, and hexagonality of cells.

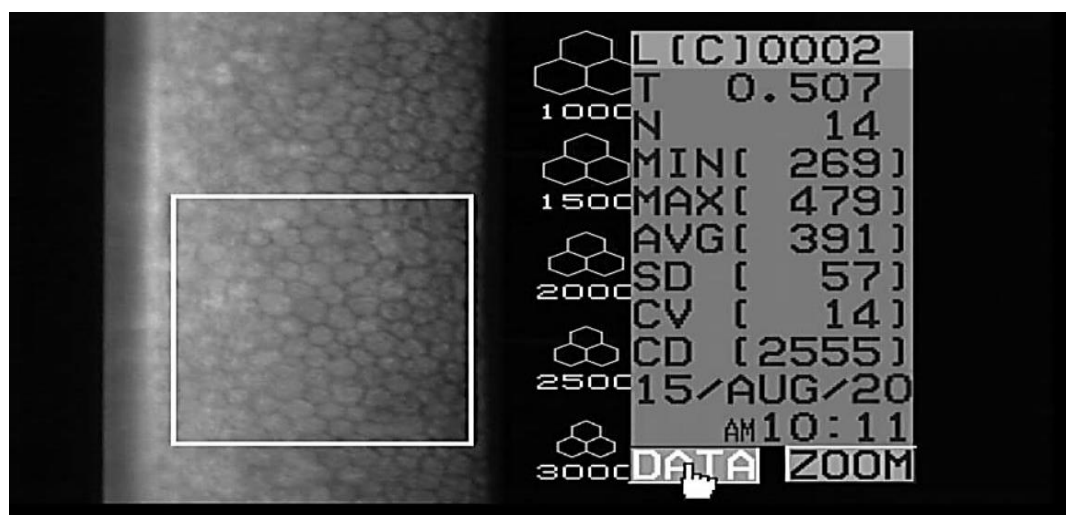

Figure (1): A specular microscopic photo for a subject of his left eye of 24 years old male patient low myopia spherical equivalent (-3.00 D) by Topcon SP2000P specular microscope.

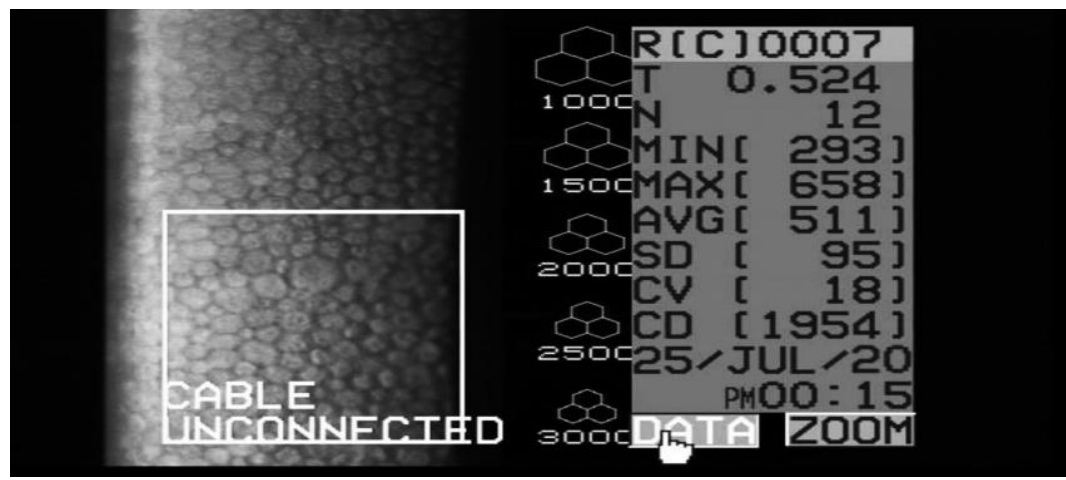

Figure (2): Specular photomicrograph of right eye of 23 years old female high myopic patient Spherical eqivalenr $(-12.00$ D) by Topcon SP2000P specular microscope.

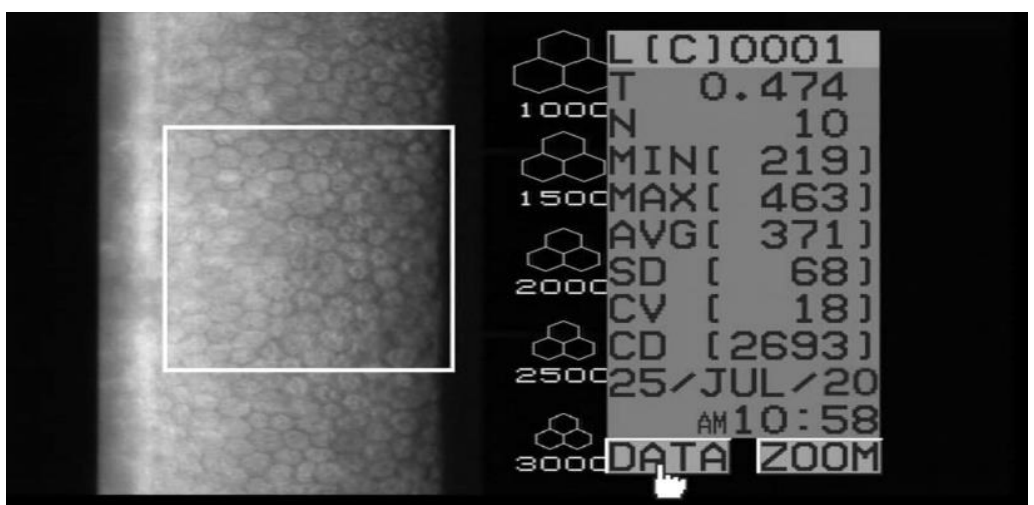

Figure (3): Specular photomicrograph of left eye of 30 years old moderate myopic male patient of Spherical equivalent (-4.55D). 


\section{Statistical Analysis:}

The collected data was revised, coded, tabulated and introduced to a PC using Statistical package for the Social Sciences (IBM Corp. Released 2011. IBM SPSS Statistics for Windows, Version 20.0. Armonk, NY: IBM Corp). Data were presented and suitable analysis was done according to the type of data obtained for each parameter. Descriptive statistics:
Median and Interquartile range (IQR) for non-parametric numerical data. Analytical statistics: Kruksall Wallis (KW) test was used to assess the statistical significance of the difference between more than two study group means. Post Hoc test was used for comparisons of all possible pairs of group means. $\mathrm{P}$ value $<0.05$ was considered significant.

\section{RESULTS}

There was a statistical significant difference ( $\mathrm{p}$-value $<0.001)$ between studied groups as regard ECD (Table 1).

Table (1): Comparisons between studied groups as regard ECD by KW test

\begin{tabular}{|c|c|c|c|c|}
\hline ECD & $\begin{array}{c}\text { Low Myopia } \\
(\mathbf{n}=\mathbf{4 0})\end{array}$ & $\begin{array}{c}\text { Moderate } \\
\text { myopia } \\
(\mathbf{n = 4 0 )}\end{array}$ & $\begin{array}{c}\text { High } \\
\text { myopia } \\
(\mathbf{n = 4 0 )}\end{array}$ & \multirow{2}{*}{ P-value } \\
\cline { 1 - 4 } Median & 2992 & 2690 & 2531 & \multirow{2}{*}{$<0.001$} \\
\hline IQR & $2850: 3332$ & $2542: 2938$ & $2147: 2789$ & \\
\hline
\end{tabular}

There was a statistical significant difference between low and moderate myopia groups, low and high myopia groups and moderate and high myopia groups (Table 2).

Table (2): Post-Hoc test for multiple comparisons between studied groups as regard ECD and CV\%

\begin{tabular}{|c|c|c|c|}
\hline \multicolumn{2}{|c|}{$\begin{array}{ll}\text { Groups } & \text { Parameters } \\
\end{array}$} & ECD & p-value \\
\hline \multirow{3}{*}{ ECD } & Low myopia & $\begin{array}{c}\text { Moderate myopia } \\
\text { High myopia }\end{array}$ & $\begin{array}{l}<0.001 \\
<0.001\end{array}$ \\
\hline & Moderate myopia & $\begin{array}{l}\text { Low myopia } \\
\text { High myopia }\end{array}$ & $\begin{array}{c}<0.001 \\
0.028\end{array}$ \\
\hline & High myopia & $\begin{array}{c}\text { Low myopia } \\
\text { Moderate myopia }\end{array}$ & $\begin{array}{c}<0.001 \\
0.028 \\
\end{array}$ \\
\hline \multirow{3}{*}{ CV\% } & Low myopia & $\begin{array}{c}\text { Moderate myopia } \\
\text { High myopia }\end{array}$ & $\begin{array}{l}<0.001 \\
<0.001\end{array}$ \\
\hline & Moderate myopia & $\begin{array}{l}\text { Low myopia } \\
\text { High myopia }\end{array}$ & $\begin{array}{l}<0.001 \\
<0.001\end{array}$ \\
\hline & High myopia & $\begin{array}{c}\text { Low myopia } \\
\text { Moderate myopia }\end{array}$ & $\begin{array}{l}<0.001 \\
<0.001\end{array}$ \\
\hline
\end{tabular}


There was a statistical significant difference $(\mathrm{p}$-value $<0.001)$ between studied groups as regard hexagonal cells $\%$. CCT (Table 3).

Table (3): Comparisons between studied groups as regard Hexagonal cells \% and CCT

\begin{tabular}{|c|c|c|c|c|c|}
\hline \multirow{2}{*}{ Parameters } & Group & $\begin{array}{c}\text { Low } \\
(\mathbf{n = 4 0})\end{array}$ & $\begin{array}{c}\text { Moderate } \\
(\mathbf{n = 4 0})\end{array}$ & $\begin{array}{c}\text { High } \\
(\mathbf{n = 4 0})\end{array}$ & \multirow{2}{*}{ P-value } \\
\hline \multirow{2}{*}{$\begin{array}{c}\text { Hexagonal } \\
\text { cells \% }\end{array}$} & Median & 63.5 & 53 & 54 & \multirow{2}{*}{$<0.001$} \\
\cline { 2 - 5 } & IQR & $58.3: 69.8$ & $49.3: 56$ & $49: 58.8$ & \\
\hline \multirow{2}{*}{ CCT } & Median & 522.5 & 532 & 505.5 & \multirow{2}{*}{0.002} \\
\cline { 2 - 5 } & IQR & $507.5: 549$ & $516.3: 563.3$ & $485: 541$ & \\
\hline
\end{tabular}

There was no statistical significant difference between low \& moderate myopia groups. There was statistically significant difference between low and high myopia groups and moderate and high myopia groups (Table 4).

Table (4): Post-Hoc test for multiple comparisons between studied groups as regard CCT

\begin{tabular}{|c|c|c|c|}
\hline \multirow{2}{*}{ Groups } & CCT & test & P-value \\
\hline \multirow{2}{*}{ Low myopia } & Moderate myopia & 710 & 0.386 \\
\cline { 2 - 4 } & High myopia & 515.5 & 0.006 \\
\hline \multirow{2}{*}{$\begin{array}{c}\text { Moderate } \\
\text { myopia }\end{array}$} & Low myopia & 710 & 0.386 \\
\cline { 2 - 4 } & High myopia & 467.5 & 0.001 \\
\hline \multirow{2}{*}{ High myopia } & Low myopia & 515.5 & 0.006 \\
\cline { 2 - 4 } & Moderate myopia & 467.5 & 0.001 \\
\hline
\end{tabular}

There was a statistical significant difference between studied groups as regard $\mathrm{ECD}, \mathrm{CV} \%$, hexagonal cells \%, sphere, CCT. There was no statistically significant difference between low, and moderate eyes as regard CCT and high and moderate as regard hexagonal cell (Table 5).

Table (5): Comparisons between studied groups as regard endothelial cells parameters

\begin{tabular}{|c|c|c|c|c|c|}
\hline \multicolumn{2}{|c|}{$\begin{array}{ll}\text { Parameters } & \text { Groups } \\
\end{array}$} & $\begin{array}{c}\text { Low } \\
(n=40)\end{array}$ & $\begin{array}{c}\text { Moderate } \\
(n=40)\end{array}$ & $\begin{array}{c}\text { High } \\
(n=40)\end{array}$ & P-value \\
\hline \multirow{2}{*}{ ECD } & Median & 2992 & 2690 & 2531 & \multirow{2}{*}{$<0.001$} \\
\hline & IQR & $2850: 3332$ & $2542: 2938$ & $2147: 2789$ & \\
\hline \multirow{2}{*}{ CV\% } & Median & 35 & 30 & 18.5 & \multirow{2}{*}{$<0.001$} \\
\hline & IQR & $33: 40$ & $26.3: 32.8$ & $14.3: 21$ & \\
\hline \multirow{2}{*}{ Hexagonal cells \% } & Median & 63.5 & 53 & 54 & \multirow{2}{*}{$<0.001$} \\
\hline & IQR & $58.3: 69.8$ & $49.3: 56$ & $49: 58.8$ & \\
\hline \multirow{2}{*}{ CCT } & Median & 522.5 & 532 & 505.5 & \multirow{2}{*}{0.002} \\
\hline & IQR & $507.5: 549$ & $516.3: 563.3$ & $485: 541$ & \\
\hline \multirow{2}{*}{ Sphere } & Median & -1.5 & -5.0 & -7.0 & \multirow{2}{*}{$<0.001$} \\
\hline & IQR & $-2.0:-1.0$ & $-5.0:-4.0$ & $-9.0:-6.0$ & \\
\hline
\end{tabular}




\section{DISCUSSION}

Few studies have been discussed the relationship between corneal endothelial cell density and morphology and refractive error. Despite various results, the significant changes in corneal endothelial characteristics do exist. Various types of refraction error have various corneal endothelial characteristics (Benetz et al., 2010, Chang et al., 2010 and Urban et al., 2010).

Decisions regarding corneal endothelial cell changes in individual with different types or degree of refractive error should be based on normative data derived from the underly population. This study provided data on endothelial cell parameters in a sample of low, moderate, and high myopic eyes. The results of this study have shown that corneal endothelial layer in high myopic eyes tends to have less density and hexagonal appearance of the cell compared to low and moderate myopic eyes. Although few studies have concluded that there are no significant changes in corneal endothelial parameters between different types or degree of refractive error, others have stated adversely (Benetz et al., 2010, Chang et al., 2010, Urban et al., 2010 and Saw et al., 2011).

The progression of myopia leads to elongation of the eye ball (Saw et al., 2011). As a result, the more myopic eye tends to have more enlargement of the globe. It has been suggested that as long as the eye elongate, the corneal endothelial surface area increases (Chang et al., 2010). Due to little or no mitotic activity of the corneal endothelial cells after birth, it is likely that the corneal endothelial cells have to floor the enlarged surface (Chang et al., 2010, Murphy et al., 2010 and Muller et al., 2012).

Corneal endothelial cells have to flatten to conquer the enlarged surface, it is conceivable that the possibility of polymorphism increases (Delshad and Chun, 2013).

Subsequently, the percentage of hexagonal appearance of the cells decreases (Matsuda et al., 2010 and Muller et al., 2012). In the absence of longitudinal data on the corneal endothelial cell changes preceding myopia onset, further studies are required to determine the cause-effect relationship between corneal endothelial cell changes and myopia onset. A prospective study by Delshad and Chun (2013) was carried to describe and compare the corneal endothelial cell density and morphology in young, low and moderate myopic Chinese adults. There were statistically significant differences in MCD and hexagonal appearance of the cell between low and moderate myopic eyes. So, in conclusion: The corneal endothelial cell layer in more myopic eyes tends to have less MCD and cell hexagonality compared to lower myopic eyes. Nevertheless, there is no significant difference in $\mathrm{CV}$ between low and moderate myopic eyes.

Sheng and Bullimore (2013) worked on subjects with a broad variation in age, refractive error (39.6\% had myopia over 5.00 D), and contact lens history. Age and race significantly affected endothelial cell density. Years of contact lens wear, age, and their interaction significantly affected coefficient of variation. Years of contact lens wear, age, and refractive error all independently affected the percentage of hexagonal cells. 
Urban et al. (2010) worked on patients aged from 13 to 18 years. Lens wearers and patients with external eye diseases and ocular surgery. Parameters were examined: CCT, ECD, CV of cell size. This study showed no significant differences in the corneal thickness among various degrees of myopic refractive error. Endothelial cell density (ECD) decreased in eyes with high myopia, but it was not correlated either with corneal thickness or with axial length of eyes. There was correlation between average cell area (AVG) and the degree of myopia.

Our study in contrary with Urban et al. (2010), demonstrated as regard CCT statistically significant difference between low and high myopia groups and moderate and high myopia. No statistically significance between low and moderate myopia.

\section{CONCLUSION}

The corneal endothelial cell layer in high myopic eyes tended to have less endothelial cell density, CV, and cell hexagonality compared to low and moderate myopic eyes.

The progression of myopia led to elongation of the eye ball. As a result, the more myopic eye tends to have more enlargement of the globe. So, as long as the eye elongated, the corneal endothelial surface area increased. Reduced corneal endothelial density is expected. Since corneal endothelial cells have to flatten to conquer the enlarged surface, it was conceivable the possibility of polymorphism increases. Subsequently, the percentage of hexagonal appearance of the cells decreased.

\section{REFERENCES}

1. Benetz BA, Diaconu E, Bowlin SJ, Oak SS, Laing RA and Lass JH. (2010): Comparison of corneal endothelial image analysis by Konan SP8000 noncontact and Bio-Optics Bambi systems. Cornea, 18(1):67-72.

2. Chang SW, Tsai IL, Huc FR, Linc LL and Shih YF. (2010): The cornea in young myopic adults. $\mathrm{Br} J$ Ophthalmol., 85(8):916-920.

3. Delshad S and Chun JM. (2013): Corneal endothelial cell demsity in low and moderate myopic Chinese eyes. International Journal of Ophthalmology, 6(4): 467-470.

4. Matsuda M, Yee RW and Edelhauser HF. (2010): Comparison of the corneal endothelium in an American and a Japanese population. Arch Ophthalmol., 103(1):68-70.

5. McCarey BE, Edelhauser HF and Lynn MJ. (2011): Review of Corneal Endothelial Specular Microscopy for FDA Clinical Trials of Refractive Procedures, Surgical Devices and New Intraocular Drugs and Solutions. Cornea, 27(1): 1-16.

6. Muller A, Doughty MJ and Wright L. (2012): Reassessment of the corneal endothelial cell organization in children. $\quad \mathrm{Br} \quad \mathrm{J}$ Ophthalmol., 84(7):692-696.

7. Murphy C, Alvarado J, Juster R and Maglio M. (2010): Prenatal and postnatal cellularity of the human corneal endothelium. A quantitative histologic study. Invest Ophthalmol Vis Sci., 25(3):312-322. 
8. Saw SM, Gazzard G, Au Eong KG, Tan DT and Gazzard AE. (2011): Myopia: attempts to arrest progression. $\mathrm{Br} \mathrm{J}$ Ophthalmol., 86 (11): 1306-1311.

9. Sheng $\mathbf{H}$ and Bullimore MA. (2013): Factors affecting corneal endothelial morphology. Cornea, 26(5):520-525.

10. Sudhir RR, Raman $R$ and Sharma T. (2012): Changes in the corneal endothelial cell density and morphology in patients with type 2 diabetes mellitus: a population-based study, Sankara Nethralaya Diabetic Retinopathy and Molecular Genetic Study (SNDREAMS, Report 23). Cornea, 31: 1119-22

11. Urban B, Bakunowicz-Lazarczyk A and Kretowska M. (2010): Corneal endothelium in children and adolescents with myopia. Klin Oczna., 104(5-6):381-383.

12. Wong TY, Ferreira A, Hughes R, Carter G and Mitchell P. (2014): Epidemiology and disease burden of pathologic myopia and myopic choroidal neovascularization: An evidence-based systematic review. Am. J. Ophthalmol., 157: 9-25.

13. Younan C, Mitchell P, Cumming RG, Rochtchina $E$ and Wang JJ. (2010): Myopia and incident cataract and cataract surgery: the Blue Mountains eye study. Invest Ophthalmol Vis Sci., 43(12):36253632. 


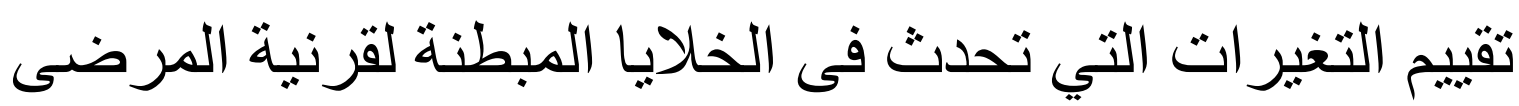

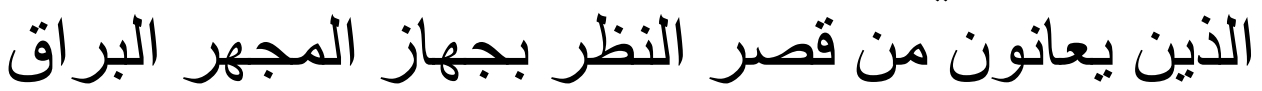

محمود الصياد، مجدي خلاف، حسن بيومي قسم طب وجراحة العيون، كلية الطب، جامعة الأزهر، مصر

E-mail: mahmoudelsayyad66@gmail.com

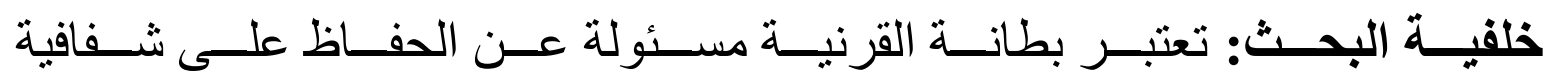

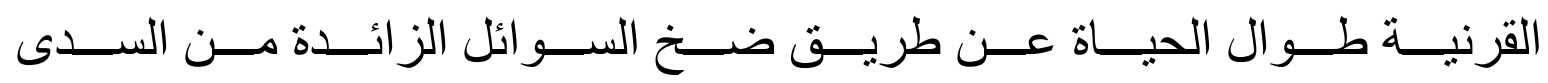

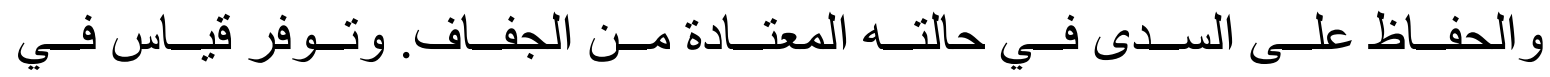

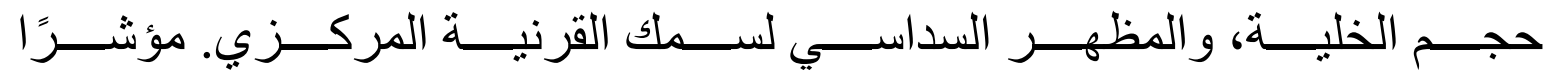

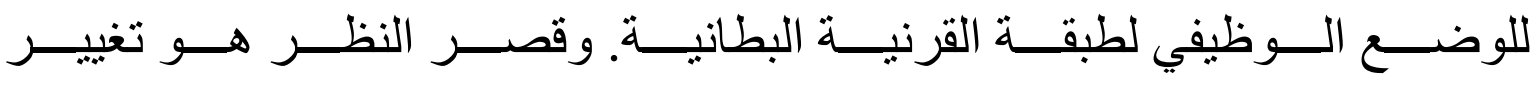
مرضي شائع للعين.

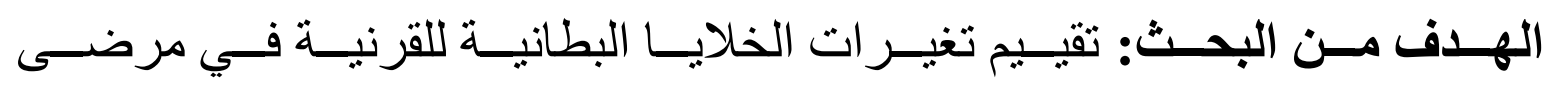
قصر النظر مجهر مرآوي غير مباشر.

المرضــى وطـــرق البحــث: تـــم إجــر اء در اســـة مســتقبلية خاضــــة للرقابــة

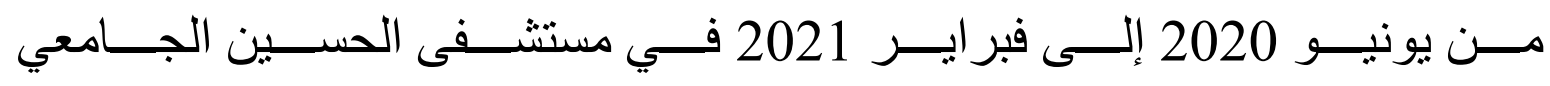

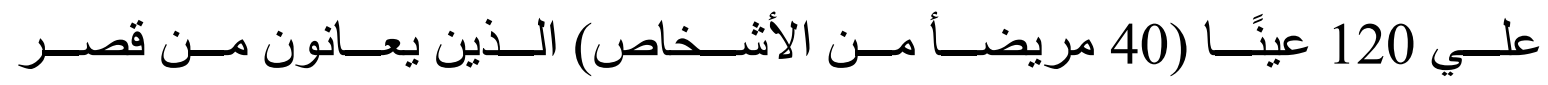

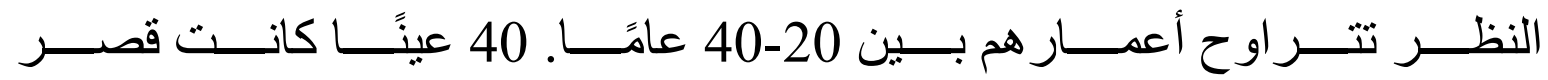
نظـــر مــنخفض >-3.00 ديــوبتر، 40 كانـــت العبــون عبــارة عـن قصـــر نظـــر معتــدل مــن (-3.00) إلــى (-6.00)، و 40 عــين مــن الأشـــخاص ذوي قصر النظر العالي> -6.00 ديوبتر.

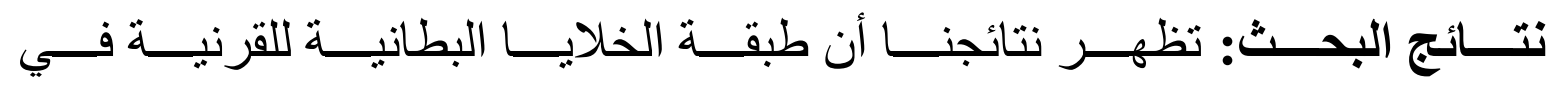

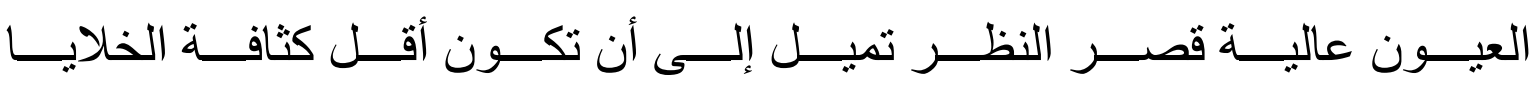




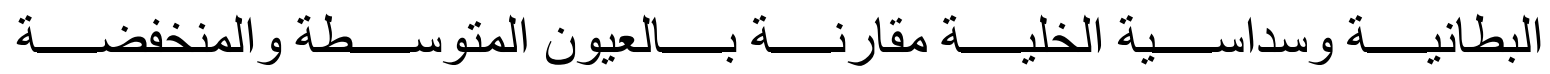

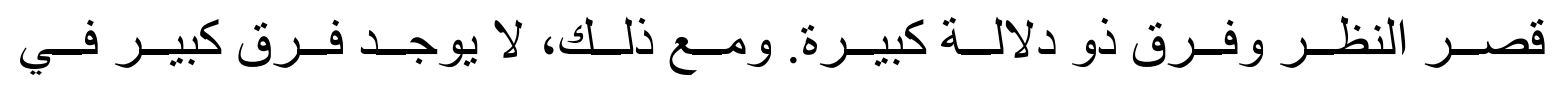

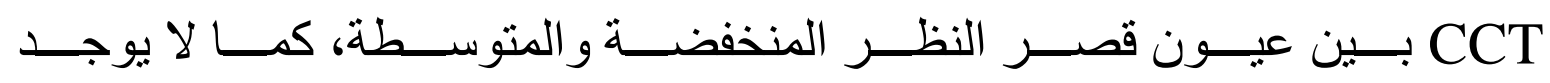

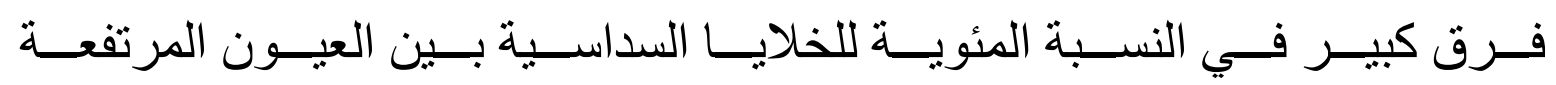
و المتوسطة قصر النظر.

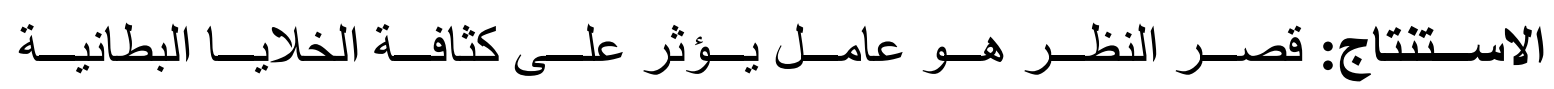
القرنية ونتكلها.

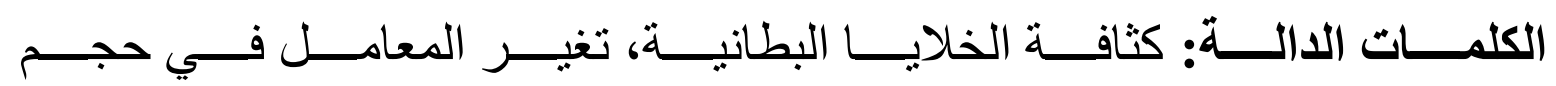

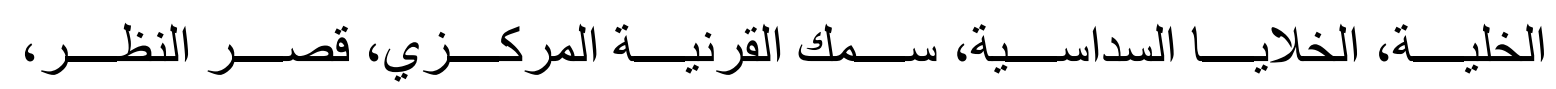
الفحص المجهري. 